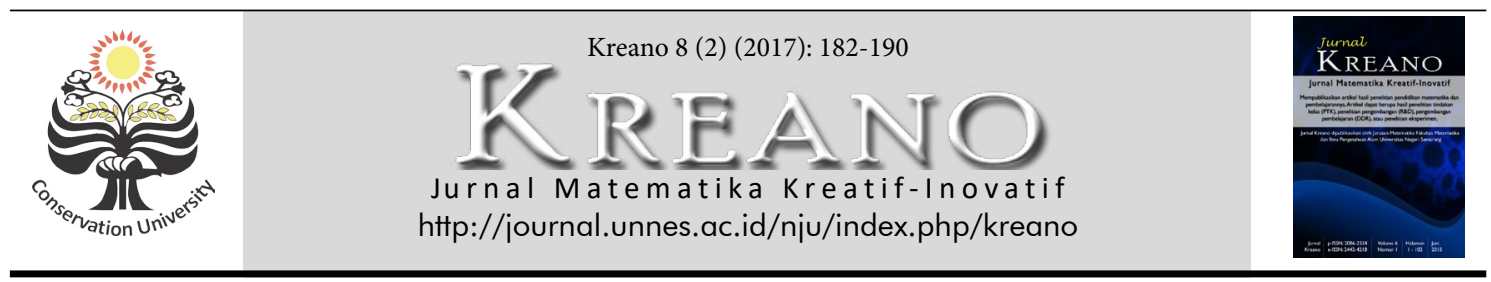

\title{
Pembentukan Keterampilan Pemecahan Masalah melalui Model IDEAL Problem Solving dengan Teori Pemrosesan Informasi
}

\author{
Akhmad Nayazik ${ }^{1}$ \\ 'Jurusan Pendidikan Matematika, IKIP Veteran Semarang \\ Email: akhmad_nayazik@ymail.com
}

DOI: http://dx.doi.org/10.15294/kreano.v8i2.7163

Received : Septembet 2016; Accepted: September 2017; Published: December 2017

\begin{abstract}
Abstrak
Penelitian ini bertujuan untuk membentuk keterampilan pemecahan masalah melalui model IDEAL Problem Solving. Penelitian ini merupakan penelitian kualitatif kolaboratif dengan teknik pengambilan subjek penelitian yaitu purposive sampling. Pengambilan sampel dengan pertimbangan tertentu terfokus pada keterampilan pemecahan masalah subjek penelitian. Subjek penelitian terdiri dari subjek S.A, S.B, S.C, dan S.D. Keempat subjek penelitian dilakukan pengamatan, alat perekaman, dan wawancara untuk menggali informasi mendalam dan pendapat, sehingga diperoleh gambaran keterampilan pemecahan masalah subjek penelitian. Hasil penelitian menunjukkan bahwa keterampilan pemecahan masalah S.A, S.B, S.C., dan S.D melalui model IDEAL Problem Solving dengan teori pemrosesan informasi dapat terbentuk.
\end{abstract}

\begin{abstract}
This research aims to form problem solving skills through IDEAL Problem Solving model. This research was a qualitative collaborative research. The technique of research subject taking was purposive sampling. Sampling with particular consideration focuses on problem solving skills of research subjects. Research subjects consist of subjects S.A, S.B, S.C, and S.D. The four subjects of the study were observed, recorded, and interviewed to explore in-depth information and opinions, to obtain a description of the problem solving skills of the research subjects. The results show that problem solving skills of S.A, S.B, S.C., and S.D through IDEAL Problem Solving model with information processing theory can be formed.
\end{abstract}

Keywords: problem solving skills; IDEAL problem solving; information processing theory

\section{PENDAHULUAN}

Menurut Lampert, Stein, Smith, Henningsen, dan Silver (Silver, 2016) pemecahan masalah merupakan kegiatan inti dalam kelas matematika di semua jenjang pendidikan di seluruh dunia. Masalah adalah pusat untuk pengajaran matematika, pembelajaran, dan dasar untuk aktivitas intelektual di kelas. Dengan demikian, masalah matematika membentuk siswa untuk belajar matematika. Pada akhirnya, antisipasi, pengecekan dan evaluasi tugas siswa pada masalah merupakan sebagian besar dari tugas guru matematika. Hal ini sejalan dengan penelitian yang dilakukan oleh (Jitendra, Harwell, Dupuis, \& Karl, 2016) bahwa ketika siswa diberikan instruksi yang tepat, kesulitan matematika dalam pemecahan masalah dapat meningkatkan kinerja pemecahan masalah secara proporsional.

Pemecahan masalah umumnya dianggap sebagai aktivitas kognitif yang paling penting dalam konteks sehari-hari dan professional. Namun, belajar untuk memecahkan masalah diperlukan pengaturan tingkatan pendidikan formal karena pemahaman tentang proses yang terbatas (Jonassen, 2000). 
Pemecahan masalah merupakan komponen penting dari kurikulum matematika dan didalamnya terdapat inti dari aktivitas matematika, sehingga kemampuan pemecahan masalah di kalangan siswa perlu mendapat perhatian dalam pembelajaran (Nayazik, Sukestiyarno, \& Hindarto, 2013).

Untuk melatih kreativitas siswa diperlukan kegiatan yang memberikan kesempatan pada siswa untuk menggunakan daya pikir, mengembangkan ide, menemukan solusi suatu masalah agar mereka dapat mengembangkan kemampuan pemecahan masalah dengan baik, diperlukan suatu model pembelajaran yang tepat. (Bransford \& Stein, 1993) memperkenalkan IDEAL Problem Solving sebagai model pembelajaran yang dapat membantu untuk menyelesaikan masalah. IDEAL Problem Solving dapat digunakan untuk menyelesaikan masalah dengan soal/masalah yang terdefinisi dengan baik (well structured problem). Langkah-langkah dalam pembelajaran model IDEAL Problem Solving adalah (1) mengidentifikasi masalah, (2) mendefinisikan tujuan,(3) menggali solusi, (4) melaksanakan strategi, dan (5) mengkaji kembali dan mengevaluasi dampak dari pengaruh.

Dewasa ini, setiap proses dipandang sebagai rangkaian sejumlah subproses yang masing-masing memegang peranan terbatas dalam keseluruhan proses belajar; setiap subproses berlangsung selama jangka waktu tertentu. Padangan ini bersumber pada teori belajaryang dikenal sebagai teori pemrosesan informasi (information processing). Dengan menggunakan teori pemrosesan informasi yang didalamnya berpikir sebagai suatu kejadian atau peristiwa dalam "otak" yang meliputi urutan langkah pengolahan informasi dari saat diterima sampai saat dilepaskan lagi (Winkel, 2009). Hasil penelitian menunjukkan bahwa ketertarikan dan prestasi sebagian besar siswa meningkat drastis apabila mereka diberi kesempatan dan difasilitasi untuk membuat hubungan antara informasi atau pengetahuan yang telah dimiliki sebelumnya. Keterlibatan siswa dalam kegiatan pembelajaran juga sangat meningkat saat mereka difasilitasi untuk mengetahui tujuan pembelajaran (Sugiyono, Murdanu, \& Murdiyani, 2014).

Peneliti telah melakukan observasi ke- giatan pembelajaran dan wawancara dengan guru matematika kelas $X$ di SMA Islam Sultan Agung 3 Semarang. Berdasarkan hasil observasi tersebut, diketahui bahwa keterampilan pemecahan masalah masih rendah. Selain itu, diketahui pula bahwa guru masih menggunakan model konvensional dan tidak diadakan pengamatan keterampilan pemecahan masalah sehingga kurang mengetahui perkembangan keterampilan kemampuan siswa belum sepenuhnya optimal.

Dalam memahami materi dimensi tiga, diperlukan suatu proses pada diri siswa untuk mencoba, dan melakukan analisis pada suatu obyek. Dengan adanya suatu usaha dalam proses diharapkan siswa dapat menunjukkan perubahan hasil belajarnya menjadi lebih baik, pada ranah kognitif, afektif, maupun psikomotoriknya. Sehingga diperlukan suatu usaha yang melibatkan siswa aktif, yang nampak dari aktivitas yang harus diperhatikan, sehingga akan menunjukkan suatu perubahan hasil belajar yang optimal. Dari latar belakang di atas, diperlukan adanya pembelajaran matematika model IDEAL Problem Solving dengan teori pemrosesan informasi untuk pembentukan keterampilan pemecahan masalah.

Berdasarkan latar belakang diatas, masalah penelitian difokuskan pada pembentukan keterampilan pemecahan masalah dengan model IDEAL Problem Solving dengan teori pemrosesan informasi. Tujuan penelitian adalah membentuk keterampilan pemecahan masalah melalui model Problem Solving dengan teori pemrosesan informasi.

\section{METODE}

Penelitian ini merupakan penelitian kualitatif kolaboratif yaitu peneliti bekerja sama dengan guru mata pelajaran matematika dalam memperoleh data penelitian. Penentuan subjek penelitian dilakukan dengan teknik purposive sampling. Populasi yang digunakan dalam penelitian ini semua siswa kelas X SMA Islam Sultan Agung 3 Semarang yang mempunyai dua kelas dengan jumlah 56 siswa. Pengambilan sampel dilakukan dengan teknik purposive sampling, didapatkan beberapa siswa kelas X-2 yaitu S.A, S.B, S.C, dan S.D yang mewakili kelompok pilihan yaitu pemberian tes pendahuluan dan hasilnya diranking. Ke- 
mudian dengan pertimbangan pada hasil tersebut, maka diambil siswa rangking 2 teratas pada kelompok 1 dan 3, sedangkan pada kelompok 2 hanya diambil 1 orang.

Pada penelitian kualitatif yang menjadi instrumen kunci adalah peneliti. Untuk memperoleh kelengkapan data, digunakan instrumen penunjang yaitu lembar observasi, pedoman wawancara, alat perekam serta catatan lapangan. Untuk analisis data, pada penelitian ini digunakan analisis data kualitatif, yaitu reduksi data, penyajian data, dan penyimpulan data. Mereduksi berarti merangkum, memilih hal-hal pokok, dan memfokuskan pada masalah yang ingin dianlisis. Dengan reduksi data, maka gambaran kemampuan yang akan diperoleh akan semakin jelas. Setelah data direduksi, kemudian data disajika. Penyajian data dapat dilakukan dalam bentuk uraian singkat. Dengan penyajian data, maka akan memudahkan memahami apa yang terjadi, dan dapat digunakan untuk merencanakan apa yang akan dilakukan selanjutnya. Setelah data disajikan kemudian dilakukan penarikan kesimpulan. Hasil kesimpulan berupa deskripsi atau gambaran suatu objek atau kemampuan yang sedang diteliti.

\section{HASIL DAN PEMBAHASAN}

Penelitian ini bertujuan untuk membentuk keterampilan pemecahan masalah subjek penelitian. Oleh karena itu, dalam kegiatan pra-pembelajaran, pembelajaran, dan pascapembelajaran guru melakukan pengamatan terhadap proses pemecahan masalah dan hasil pemecahan masalah subjek penelitian ketika pembelajaran berlangsung dan melakukan wawancara di akhir pembelajaran. Data tersebut dideskripsikan untuk mengetahui perkembangan keterampilan pemecahan masalah selama penelitian berlangsung.

Keterampilan pemecahan masalah S.A yang memperoleh rangking terakhir dalam tes pendahuluan. Keterampilannya dalam menyelesaikan masalah pada tes pendahuluan masih sangat kurang. S.A belum biasa memahami soal dengan baik, masih kesulitan untuk melakukan pemecahan masalah. Perlu adanya perhatian untuk dapat meningkatkan pemrosesan kognitif siswa dalam memahami permasalahan. Pemrosesan informasi yang datang memerlukan perhatian selektif terhadap kejadian, objek, simbol, dan stimulis tertentu lainnya agar informasi itu dapat dipelajari. Hasil pekerjaan Subjek S.A dapat dilihat pada Gambar 1.

Secara umum untuk pertemuan-pertemuan berikutnya S.A dapat memilih strategi pemecahan masalah dan lebih cepat melakukan perhitungan. Hasil yang diperoleh subjek penelitian S.A dalam pengamatan keterampilan pemecahan masalah dari pertemuan I-V. yaitu digambarkan dalam Grafik 1.

Dari Gambar 2, dijelaskan bahwa pada

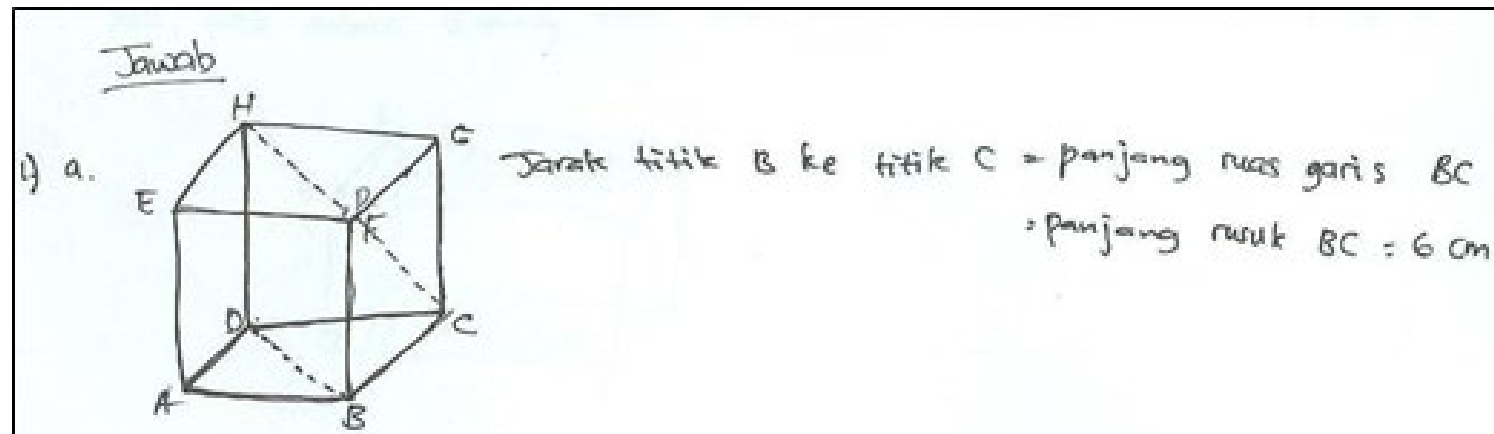

b. Jarak titik B ke fitik D. penjeng ruas garis $B D$

$B D$. Diagonal sisi

$B D=a \sqrt{2}$

$=6 \sqrt{2} \mathrm{~cm}$.

Gambar 1. Pemecahan Masalah S.A 


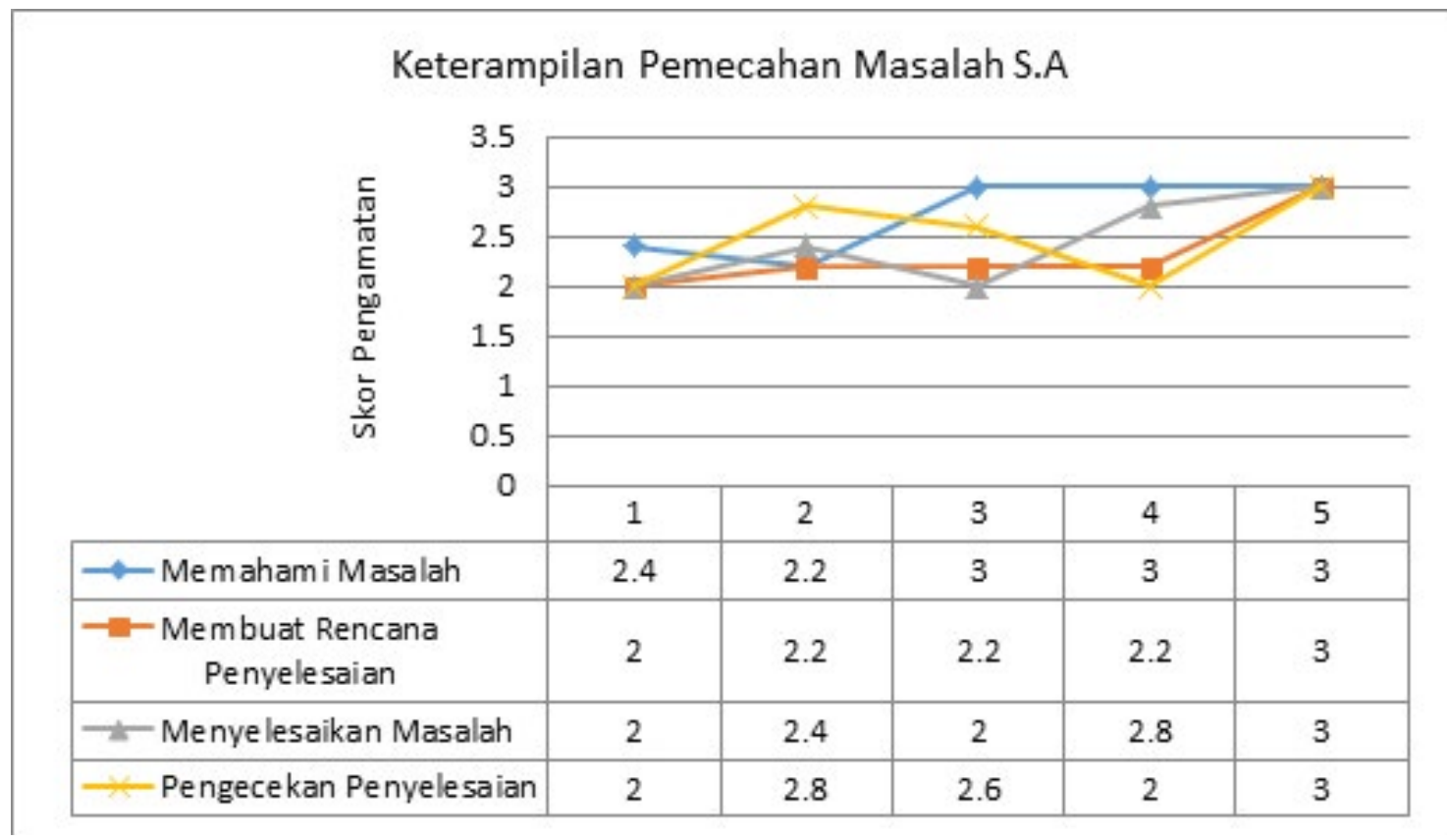

Gambar 2. Grafik Hasil Pengamatan Keterampilan Pemecahan Masalah S.A

pertemuan I S.A sudah memperoleh rata-rata dari setiap indikator. Pada pertemuan II-IV S.A tidak mengalami peningkatan dalam membuat rencana pemecahan masalah. Pertemuan III-V S.A dalam memahami masalah tidak mengalami peningkatan. Hal ini menunjukkan bahwa S.A memiliki dasar keterampilan pemecahan masalah yang cukup baik dalam memahami, membuat rencana penyelesaian, menyelesaikan atau bahkan pengecekan kembali. Hasil pekerjaan Subjek S.A terkait hal tersebut di atas, dapat dilihat pada Gambar 3 .

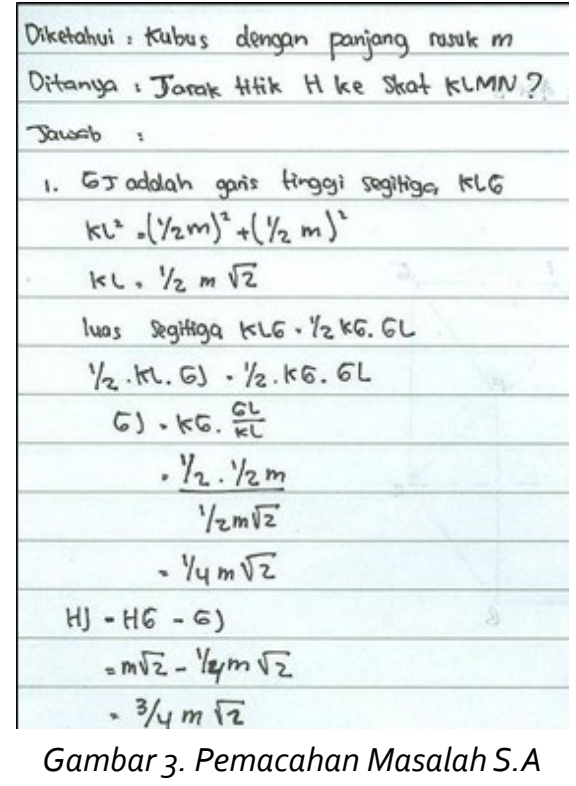

Keterampilan pemecahan masalah S.B masih kurang saat mengerjakan tes pendahuluan. Hasil tes menunjukkan bahwa selain belum bisa memahami masalah, S.B juga belum dapat merencanakan dan melaksanakan strategi pemecahan masalah yang tepat. S.B tidak menuliskan jawaban sesuai tahap-tahap pemecahan masalah mulai yang diketahui dan seterusnya, ia lebih suka menggunakan cara langsungan dan hanya menuliskan jika disuruh. Hasil pekerjaan Subjek S.B terkait hal tersebut di atas data dilihat pada Gambar 4.

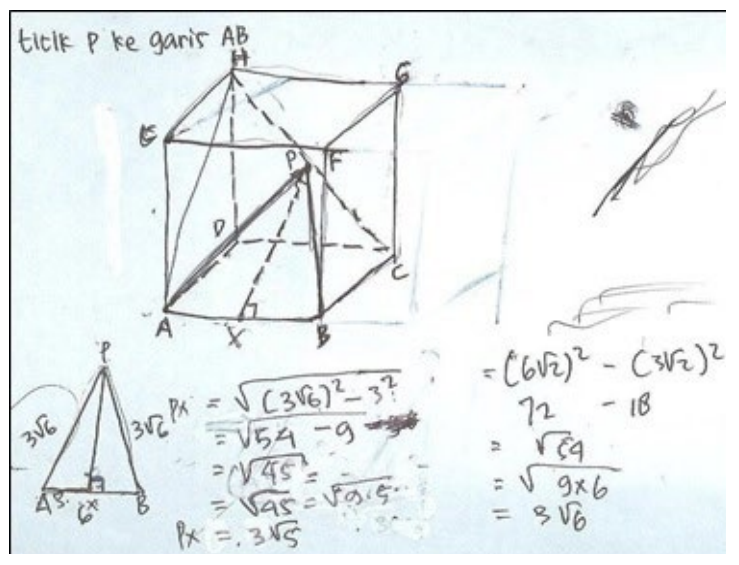

Gambar 4. Pemecahan Masalah S.B 


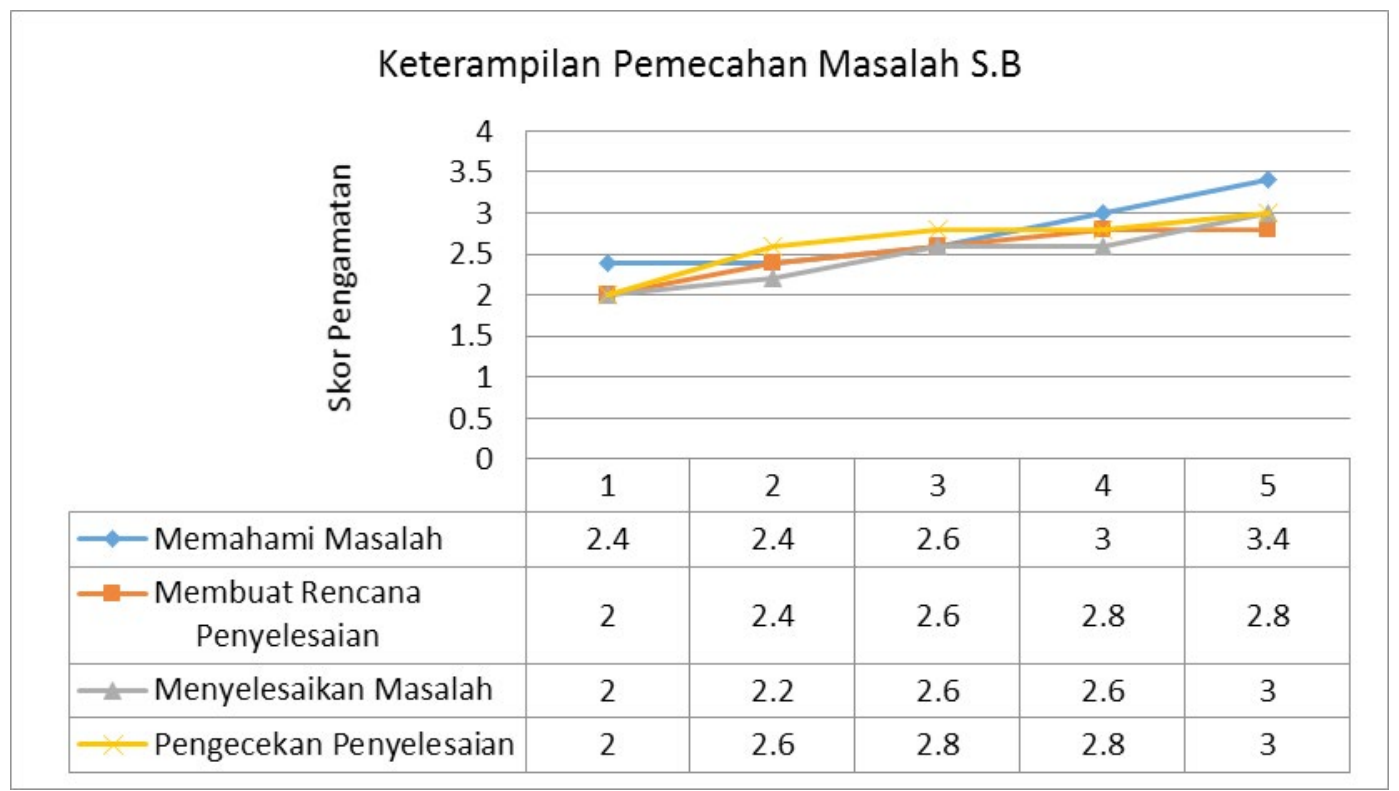

Gambar 5. Grafik Hasil Pengamatan Keterampilan Pemecahan Masalah S.B

Berdasarkan hasil tersebut terlihat bahwa S.B sudah dapat memahami masalah akan tetapi belum menuliskan apa yang diketahui dan apa yang ditanyakan. Pada tahap penyelesaian, S.B belum menuliskan apa yang hendak dicari secara lengkap seperti dengan bantuan garis AH. S.B belum menuliskan kesimpulan pemecahan masalahnya.

Secara umum untuk pertemuan-pertemuan berikutnya S.B dapat memilih strategi yang tepat dalam pemecahan masalah, kekurangannya masih sering tidak teliti, kesulitan dalam menggunakan teorema phytagoras terkadang dialaminya, dan lupa menuliskannya apa yang dihitung. Hasil yang diperoleh subjek penelitian S.B dalam pengamatan keterampilan pemecahan masalah dari pertemuan I-V, yaitu digambarkan dalam Gambar 5.

Dari Gambar 5, dapat dijelaskan bahwa pada pertemuan I S.B sudah memperoleh rata-rata dari setiap indikator. Pada pertemuan I-II tidak mengalami peningkatan dalam memahami masalah. Akan tetapi, pada pertemuan I-V mengalami peningkatan yang baik dalam memahami masalah. Pada pertemuan III-IV S.B dalam menyelesaikan masalah tidak mengalami peningkatan. Hal ini menunjukkan bahwa S.B memiliki dasar keterampilan pemecahan masalah yang cukup baik dalam memahami, membuat rencana penyelesai- an, menyelesaikan atau bahkan pengecekan kembali.

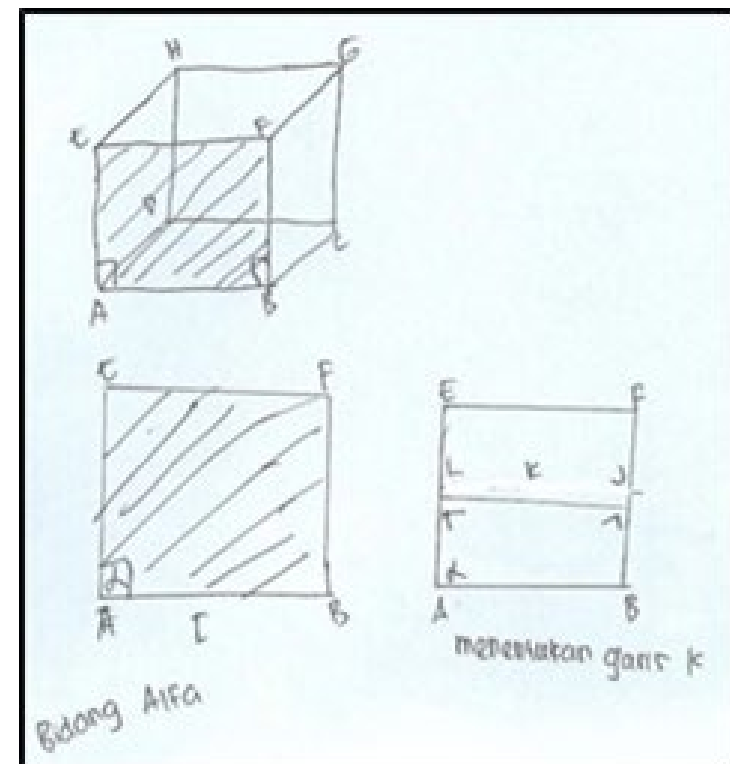

Gambar 6. Sketsa Pemecahan Masalah S.B.

Keterampilan pemecahan masalah S.C dapat menuliskan langkah-langkah pemecahan masalah secara sistematis dan rapi, namun dalam beberapa masalah ia masih kesulitan dalam memilih dan menggunakan strategi yang tepat. Ketika pada pertemuan III diberikan masalah untuk dikerjakan, S.C menuliskan secara runtut apa yang diketahui dan 


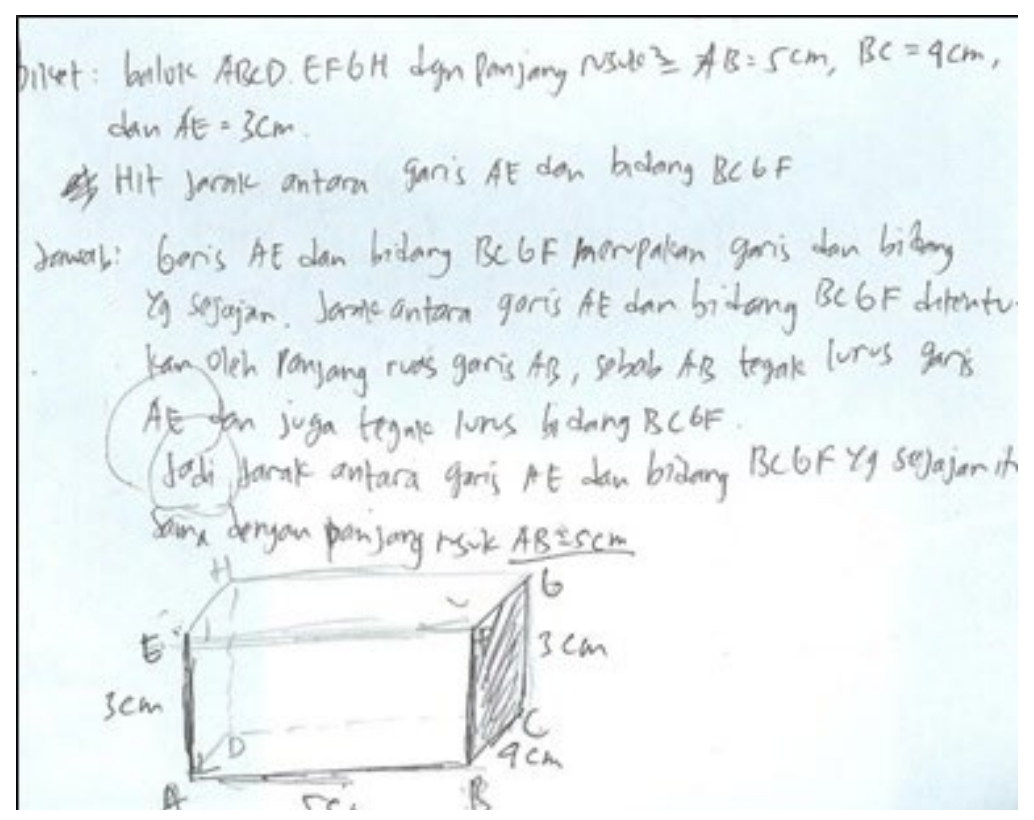

Gambar 7. Pemecahan Masalah S.C

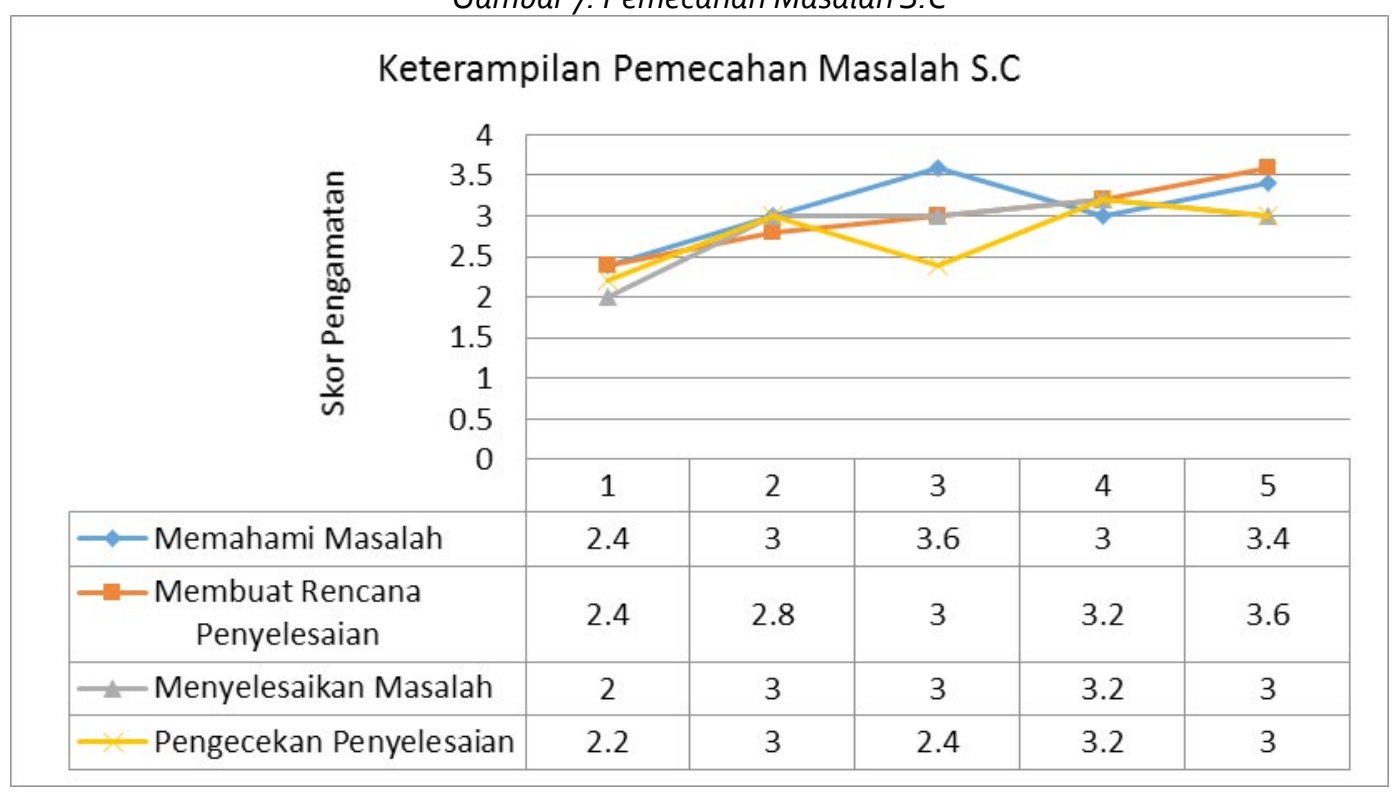

Gambar 8. Grafik Hasil Pengamatan Keterampilan Pemecahan Masalah S.C

ditanyakan. Hasil pekerjaan Subjek S.C dapat dilihat pada Gambar 7.

Dari Gambar 8, dapat dijelaskan bahwa pada pertemuan I S.C sudah memperoleh rata-rata dari setiap indikator. Pada pertemuan I-V S.C dalam memahami masalah dan membuat rencana penyelesaian mengalami peningkatan yang baik.Akan tetapi, pada pertemuan II-III dalam menyelesaikan masalah tidak mengalami peningkatan. Pada pertemuan II-III S.C mengalami penurunan dalam pengecekan penyelesaian karena kurang teliti dalam pengecekan kembali. Hal ini menun- jukkan bahwa S.C memiliki dasar keterampilan pemecahan masalah yang baik dalam memahami, membuat rencana penyelesaian, menyelesaikan atau bahkan pengecekan kembali. Hasil pekerjaan Subjek S.C sebagaimana terkait penejlasan di atas, dapat dilihat pada Gambar 9.

Keterampilan pemecahan masalah S.D hasil tes pendahuluan menunjukkan bahwa keterampilan pemecahan masalah S.D baik, ia mampu mengorganisasikan apa yang diketahui dan merancang strategi yang tepat untuk memecahkan masalah. Kekurangannya ada- 


\begin{tabular}{|c|c|}
\hline \multirow{2}{*}{\multicolumn{2}{|c|}{ 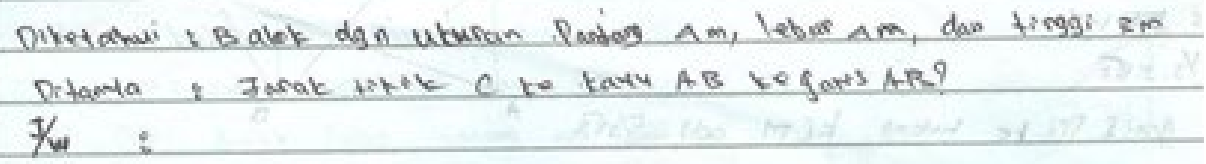 }} \\
\hline & \\
\hline & 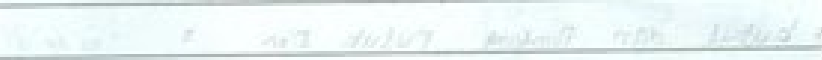 \\
\hline Wakt metroot & $C Q$ Panlu hencast Padary AC,CB dem $A B$ \\
\hline$\quad A C^{2}=A^{2}+3^{2}$ & $C D^{2}=A C^{2}-Y=(A B)^{2}$ \\
\hline+1649 & $=25-y_{2}(4 \sqrt{2})^{2}$ \\
\hline .25 & $=25-6 \cdot 3 x$ \\
\hline$M C=\sqrt{a r}+5$ & $=25-16$ \\
\hline$A R^{2}+A^{2}+A^{2}$ & a) 7 \\
\hline $.16+16$ & $C D=\sqrt{9} \cdot 3 m$ \\
\hline$=32$ & 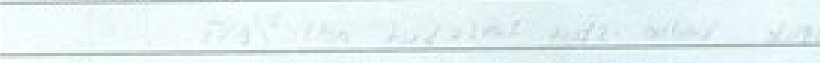 \\
\hline$A(2, \sqrt{32} \times A \sqrt{2}$ & jedi tasak wetik $C$ te gaoss $A B$ adl $3 \mathrm{~m}$ \\
\hline
\end{tabular}

Gambar 9. Pemecahan Masalah S.C

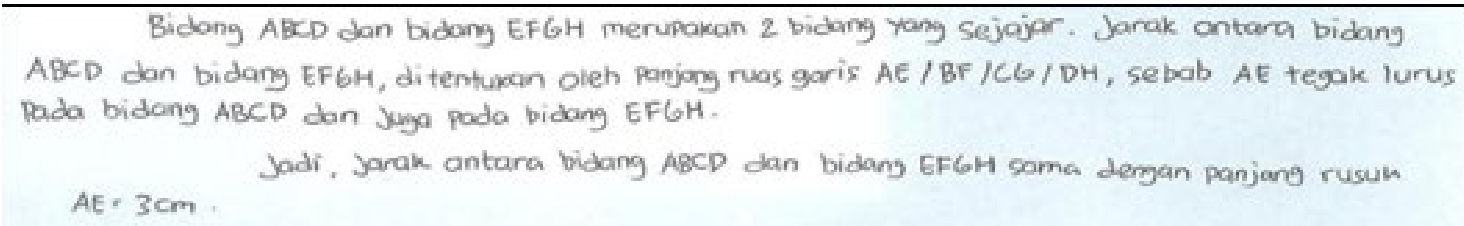

Gambar 10. Pemecahan Masalah S.D

lah belum dapat menuliskan langkah-langkah yang sistematis dari pemecahan masalah. Ketika pada pertemuan awal S.D diberikan masalah untuk dikerjakan, ia mengerjakan dengan cara cepat, tanpa menuliskan secara runtut apa yang diketahui, ditanyakan dan langkah-langkah. Hasil pekerjaan Subjek S.D dapat dilihat pada Gambar 10 dan 11.

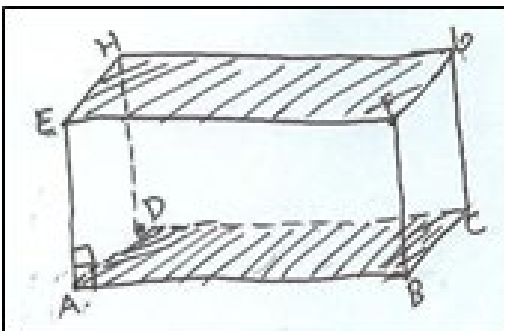

Gambar 11. Sketsa Pemecahan Masalah S.D

Secara umum untuk pertemuan-pertemuan berikutnya S.D dapat lancar dan terampil dalam memecahkan masalah, hanya saja terdapat beberapa kesalahan yang berkaitan dengan ketelitian perhitungan akhir.Hasil yang diperoleh subjek penelitian S.D dalam pengamatan keterampilan pemecahan masalah dari pertemuan I-V, yaitu digambarkan dalam Grafik 4.

Dari Gambar 12, dapat dijelaskan bahwa pada pertemuan IS.D sudah memperoleh rata-rata dari setiap indikator. Pada pertemuan I-V S.D dalam memahami masalah, membuat rencana penyelesaian, menyelesaikan masalah, dan pengecekan kembali mengalami peningkatan yang baik. Akan tetapi, pada pertemuan III-IV dalam membuat rencana penyelesaian mengalami peningkatan. Pada pertemuan IV-V S.D mengalami penurunan dalam memahami masalah. Hal ini menunjukkan bahwa S.D memiliki dasar keterampilan pemecahan masalah yang baik dalam memahami, membuat rencana penyelesaian, menyelesaikan atau bahkan pengecekan kembali. Hasil pekerjaan Subjek S.D dapat dilihat pada Gambar 13. 


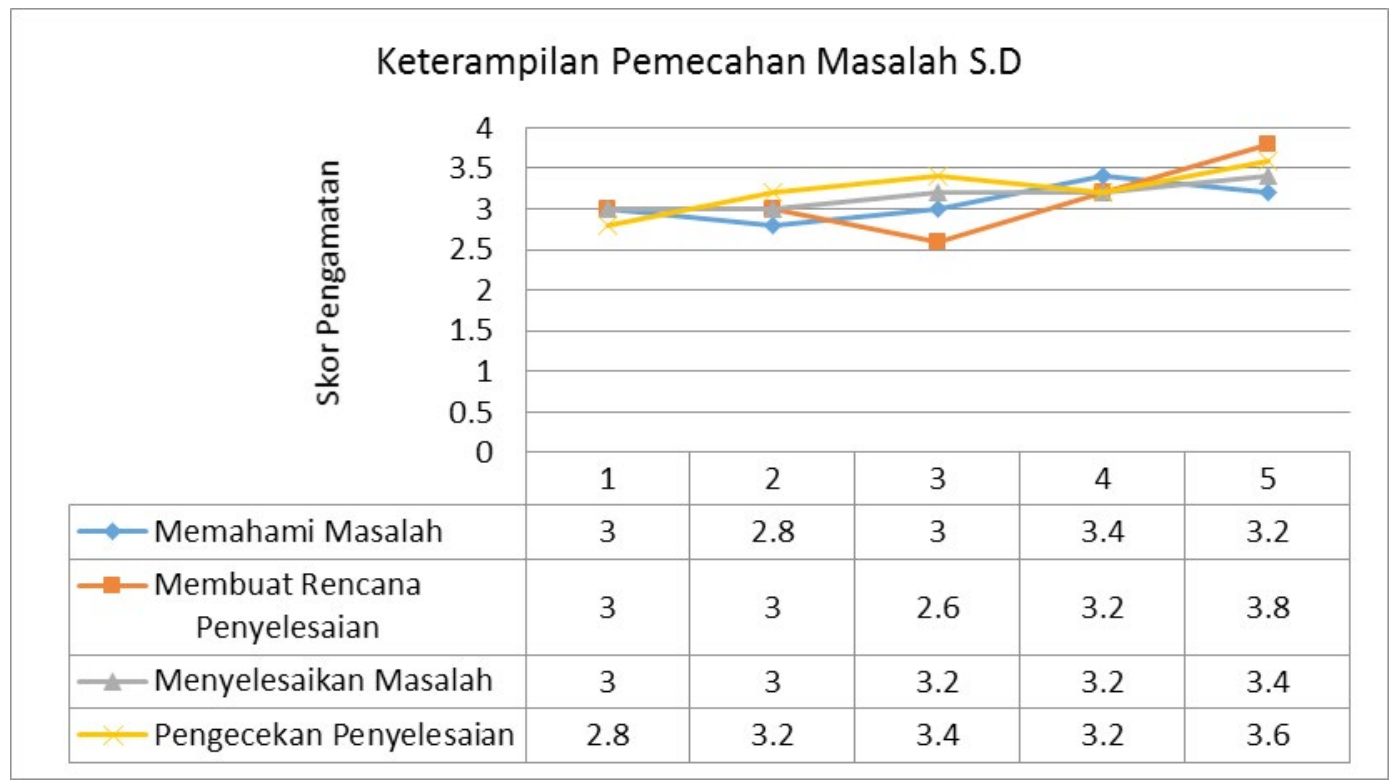

Gambar 12. Grafik hasil pengamatan keterampilan pemecahan masalah S.D

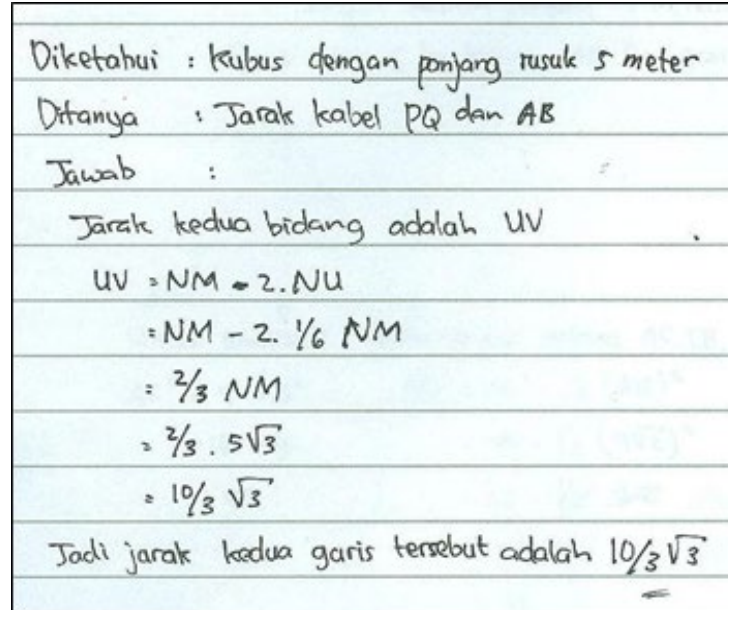

Setelah diuraikan setiap subjek pada setiap kelompok, baik atas, menengah ataupun bawah. Dapat disimpulkan bahwa pembelajaran matematika model IDEAL Problem Solving dengan teori pemrosesan informasi untuk pembentukan keterampilan pemecahan masalah, terlihat jelas peningkatan dari setiap pertemuan dari setiap kelompok. Hasil rekapitulasi dari nilai keterampilan pemecahan masalah dari semua pertemuan pada 4 siswa pilihan, dapat dilihat pada Gambar 14.

Gambar 13. Pemecahan Masalah S.D

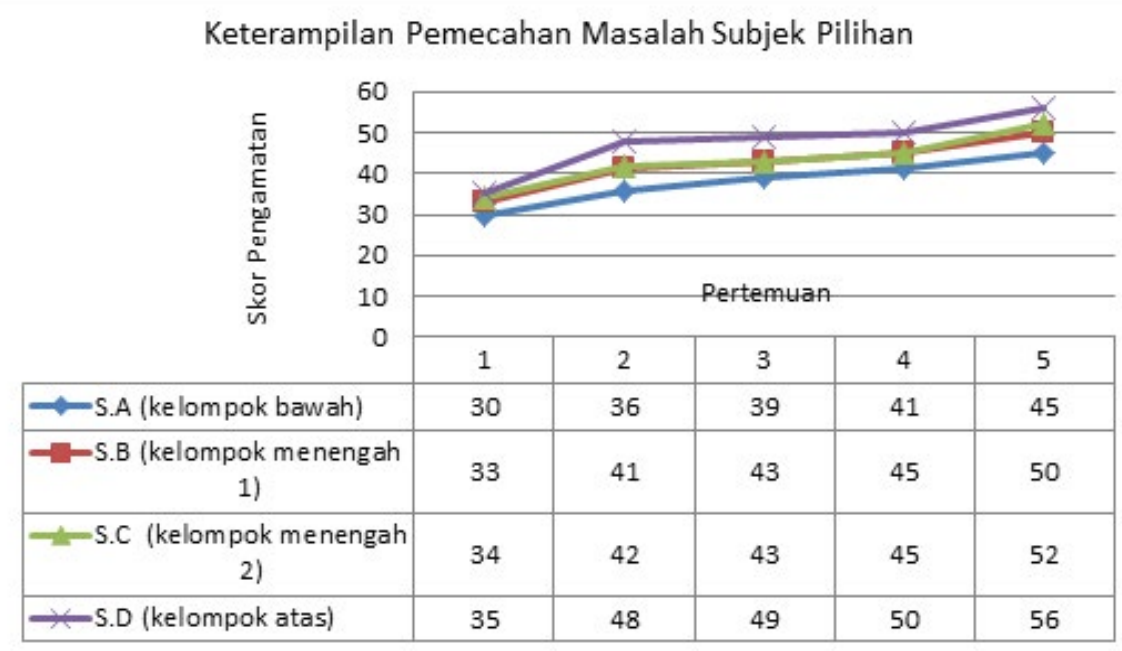

Gambar 14. Grafik Perbandingan Skor Pengamatan Karakter Rasa Ingin Tahu 


\section{Subjek Penelitian}

Dari Gambar 14, dapat disimpulkan bahwa pembelajaran matematika model IDEAL Problem Solving dengan teori pemrosesan informasi untuk pembentukan keterampilan pemecahan masalah akan lebih baik digunakan pada subjek penelitian kelompok tertentu karena dapat meningkatkan keterampilan pemecahan masalah.

Teori pemrosesan informasi menganalisis cara anak memanipulasi informasi, memonitornya, dan menciptakan strategi untuk menanganinya. Kemampuan memperhatikan informasi yang relevan meningkat dengan mantap selama tahun-tahun sekolah dasar dan menengah. Pemrosesan informasi yang datang membutuhkan perhatian yang selektif terhadap kejadian, objek, simbol, dan stimuli tertentu lainnya agar informasi itu dapat dipelajari. Penelitian lain oleh (Kulhavy, Schwartz, \& Peterson, 1986) bahwa "perhatian" siswa bisa dideskripsikan sebagai "manajer garis depan" yang penting dalam menentukan informasi yang akan diberikan untuk pemrosesan lebih lanjut. Dalam penelitian ini peran perhatian penting dalam pemrosesan informasi, tetapi bukan sumber tidak terbatas.

Penelitian lain yang dilakukan oleh (Byers \& Serences, 2012), bahwa perhatian berperan sebagai "penjaga gerbang" dengan menentukan sejauh mana persepsi dalam pembelajaran tergantung dengan tuntutan tugas. Sejalan dengan penelitian oleh (Chelazzi, Perlato, Santandrea, \& Della Libera, 2013), bahwa perhatian yang selektif dapat memaksimalkan keterampilan pemecahan masalah. Sebagai pengembangan lebih lanjut, menunjukkan bahwa perhatian dapat mempengaruhi pembelajaran. Secara khusus, perhatian yang selektif dibentuk oleh reward pembelajaran yang memerlukan pengawasan aktif dari keterampilan pemecahan masalah.

\section{PENUTUP}

Berdasarkan hasil penelitian di atas dapat disimpulkan bahwa keterampilan pemecahan masalah S.A, S.B, S.C., dan S.D melalui model IDEAL Problem Solving dengan teori pemrosesan informasi dapat terbentuk.

\section{DAFTAR PUSTAKA}

Bransford, J. D., \& Stein, B. S. (1993). The Ideal Problem Solver. Retrieved from http://digitalcommons. georgiasouthern.edu/ct2-library/46

Byers, A., \& Serences, J.T. (2012). Exploring the relationship between perceptual learning and top-down attentional control. Vision Research, 74, 30-39. http://doi.org/10.1016/j.visres.2012.07.008

Chelazzi, L., Perlato, A., Santandrea, E., \& Della Libera, C. (2013). Rewards teach visual selective attention. Vision Research, 85, 58-72. http://doi. org/10.1016/j.visres.2012.12.005

Jitendra, A. K., Harwell, M. R., Dupuis, D. N., \& Karl, S. R. (2016). A Randomized Trial of the Effects of Schema-Based Instruction on Proportional Problem-Solving for Students With Mathematics Problem-Solving Difficulties. Journal of Learning Disabilities. http://doi. org/10.1177/0022219416629646

Jonassen, D. H. (2000). Toward a design theory of problem solving. Educational Technology Research and Development, 48(4), 63-85. http://doi. org/10.1007/BFo2300500

Kulhavy, R. W., Schwartz, N. H., \& Peterson, S. (1986). Working memory: The encoding process. Cognitive Classroom Learning: Understanding, Thinking, and Problem Solving, 115-141.

Nayazik, A., Sukestiyarno, S., \& Hindarto, N. (2013). Peningkatan Karakter dan Pemecahan Masalah Melalui Pembelajaran IDEAL Problem SolvingPemrosesan Informasi. Unnes Journal of Mathematics Education Research, 2(2). Retrieved from http://journal.unnes.ac.id/sju/index.php/ujmer/ article/view/2688

Silver, E. A. (2016). Mathematical Problem Solving and Teacher Professional Learning: The Case of a Modified PISA Mathematics Task. In P. Felmer, E. Pehkonen, \& J. Kilpatrick (Eds.), Posing and Solving Mathematical Problems (pp. 345-360). Springer International Publishing. Retrieved from http://link.springer.com/chapter/10.1007/978-3-319-28023-3_20

Sugiyono, Murdanu, \& Murdiyani, N. M. (2014). Pengembangan Perangkat Pembelajaran Matematika Pada Topik Geometri Menggunakan Paradigma Baru Dalam Pembelajaran Matematika. Jurnal Pendidikan Matematika Dan Sains, 4(2), 117125.

Winkel, W. S. (2009). Psikologi pengajaran / W.S. Winkel. Psikologi Pengajaran / W.S. Winkel. Retrieved from http://library.um.ac.id/free-contents/ printbook.php/psikologi-pengajaran-w-s-winkel-38082.html 